\title{
Fish herbivory leads to shifts in seagrass Posidonia oceanica investments in sexual reproduction
}

\author{
S. Planes ${ }^{1, *}$, N. Raventos ${ }^{2,3}$, B. Ferrari ${ }^{1,4}$, T. Alcoverro ${ }^{2}$ \\ ${ }^{1}$ USR 3278, CNRS-EPHE, Centre de Biologie et d'Ecologie Tropicale et Méditerranéenne, Université de Perpignan, \\ 66860 Perpignan Cedex, France \\ ${ }^{2}$ Department of Marine Ecology, Centre d'Estudis Avançats de Blanes (CEAB-CSIC), C/ Acceso a la Cala St. Francesc 14, \\ 17300 Blanes, Girona, Spain \\ ${ }^{3}$ Present address: ARGOMARIS Private Foundation, Port of Mataró, Local DC/5C, 08301 Mataró, Spain \\ ${ }^{4}$ Present address: Agence des Aires Marines Protégées, Mission pour le parc marin de la Cote Vermeille, \\ Passage du Vieux Port, BP 05, 66660 Port-Vendres, France
}

\begin{abstract}
Although the dominant ecological paradigm considers herbivory to play an insignificant role in seagrass ecosystems, past herbivore densities were high enough to result in significant reduction of seagrass growth. To study the long-term impact of sustained and intense herbivory on seagrass meadows, we compared morphological, population and reproductive (flowering) parameters of Posidonia oceanica meadows inside a Marine Protected Area (MPA; where herbivore fish populations are very high) with unprotected meadows. In addition, we evaluated short-term seagrass responses by manipulating herbivore access to seagrass plots with caging experiments conducted inside the MPA. The density and individual sizes of the herbivorous fish Sarpa salpa were greater in the MPA, with a biomass 10 times higher than in unprotected areas. Fish bite marks on leaves were $50 \%$ more abundant inside the MPA. Shoot surface, rhizome sugar content and flower density were 80, 20 and $70 \%$ lower in the MPA, respectively, but shoot density was $30 \%$ higher in protected meadows than in unprotected meadows. The caging (fish exclusion) experiment generally corroborated these results, although the caging period was probably too short to produce changes in shoot density. P. oceanica responded to severe biomass removal by herbivores $(80 \%$ of the photosynthetic biomass) and consequent reductions in carbon storage in the rhizome by reducing sexual reproduction (flowering intensity) and by gradually increasing clonal growth (increasing shoot density). This plasticity suggests an evolutionary adaptive mechanism to deal with historically high herbivore numbers and is evidence of the importance of herbivory as a controlling process in the structuring and functioning of seagrass meadows in the past.
\end{abstract}

KEY WORDS: Herbivory $\cdot$ Seagrass $\cdot$ Posidonia oceanica $\cdot$ Mediterranean Sea $\cdot$ Sexual reproduction $\cdot$ Marine protected areas $\cdot$ Fish

\section{INTRODUCTION}

Having evolved in an environment of high herbivory, many plant species have developed a wide array of mechanisms to cope with this pressure. The disproportionate ecological success of terrestrial and marine grasses is largely due to the extreme morphological, physiological and reproductive adaptations that these groups have evolved in the face of intense herbivory
(Dublin 1995, Sinclair 1995). Plants adapted to herbivory show a great deal of plasticity in their ability to reallocate stored carbon resources, compensate growth, increase shoot density or produce chemical defences to protect the plant from intensive herbivore grazing (Harper 1977, Cumming 1982, Owen \& Wiegert 1976, McNaughton 1979, Paige \& Whitham 1987, McNaughton \& Banyikwa 1995, Ferraro \& Oesterheld 2002). This reallocation is often performed at the cost of future reproductive output, 
as plants tend to significantly modify their reproductive investment from sexual to predominantly vegetative reproduction under high herbivory (Mulder 1999, Kleijn \& Steinger 2002).

While the importance of herbivory is well recognized as a structuring agent of terrestrial grasslands, herbivore pressure is considered to be much less significant in marine seagrass meadows. Recent re-evaluations have questioned this paradigm, and it is now recognized that herbivory is much more important as a process in the structuring and functioning of seagrass meadows than previously believed (Heck \& Valentine 2006). While present herbivore densities are rarely high enough to result in significant removal of seagrass growth, herbivores can constitute an important agent in the trophic pathway in regions where their populations are high (Rose et al. 1999, Prado et al. 2007). Megaherbivores such as dugongs and turtles can sometimes reach population densities that can be locally important in structuring seagrass meadows (Preen 1995). Herbivore fish can also reach high abundances when they are protected from fishing, with potential significant grazing on seagrasses (for instance in Marine Protected Areas [MPAs]; Alcoverro \& Mariani 2004, Prado et al. 2008). Finally, population outbreaks of invertebrates such as sea urchins or molluscs can result in intense herbivore grazing (Rose et al. 1999, Alcoverro \& Mariani 2002).

Such locally high densities of herbivores are more the exception than the rule in extant seagrass meadows. However, there is increasing evidence that seagrass species, like their terrestrial counterparts, probably coevolved in environments of intense grazing, and the low herbivore densities characteristic of today's meadows are merely artefacts of historical human overexploitation of the world's oceans (Jackson et al. 2001). As with terrestrial grasses, seagrass species have several characteristics that suggest an evolutionary adaptation to herbivore resistance, e.g. inaccessible below-ground basal meristems, and branching rhizomes that enhance resistance to grazing, and belowground reserves (Valentine \& Heck 1999). In addition, individual species show considerable plasticity in the face of herbivory pressure. For instance, in clipping experiments that mimic herbivory, several seagrass species use rhizome reserves to compensate shoot reduction with aboveground growth (Alcoverro \& Mariani 2005, Vergés et al. 2008). However, although the impacts of herbivory pressure on reproductive structures (flowers) has been well documented (Piazzi et al. 2000, Balestri \& Cinelli 2003), there have been few attempts to demonstrate plant plasticity to high herbivory impacts at the population level (i.e. reproductive output and shoot dynamics, but see Peterken \& Conacher 1997, Valentine et al. 1997) This information is vital to understand whether seagrass ecosystems are as herbivore-adapted as the historical record suggests they should be. One difficulty in obtaining this populationlevel information for dominant meadow-forming species is that they often tend to be very long-lived, with slow turnover rates. For instance, individual shoots of Posidonia oceanica, the dominant seagrass in the Mediterranean Sea, can live for more than 30 yr (Marbà et al. 1996), while individual meadows can persist for millennia (Mateo et al. 1997).

In this study, we examined the plant responses of Posidonia oceanica to sustained, high herbivory in terms of sexual reproduction and vegetative growth. To do this, we compared meadows with high (MPA) and low fish herbivory (unprotected control areas). In addition, we used caging experiments within high-herbivory areas to manipulate herbivore pressure. We compared seagrass responses in terms of sexual reproduction (flowering), vegetative population growth (shoot density) and rhizome storage inside and outside the MPA and inside and outside the experimental cages.

\section{MATERIALS AND METHODS}

Two different approaches (comparative and experimental) were used to test the effect of fish herbivory on Posidonia oceanica meadows. The study was conducted in shallow meadows $(7 \mathrm{~m}$ depth), which are known to have the highest densities of herbivore fish (Harmelin-Vivien 1983, Francour 1997, Boudouresque \& Verlaque 2001, Tomás et al. 2005).

Comparing protected and unprotected meadows. The study was conducted in 9 seagrass meadows along the Albéres coast (NW Mediterranean Sea; Fig. 1). The total linear distance between meadows was $<25 \mathrm{~km}$, which enabled a comparison between meadows without the need to account for a latitudinal gradient. Three meadows were located inside the Marine Natural Reserve of Cerbère-Banyuls, established in 1972 (Fig. 1). This is sufficiently long ago for effective recovery of fish populations (abundances and sizes), including herbivore groups (McClanahan \& Arthur 2001, Russ \& Alcala 2004, McClanahan \& Graham 2005). The 6 remaining meadows were located randomly outside the MPA at sites with no fishing restrictions but otherwise similar environmental and physical features (Ferrari et al. 2008). In order to compare seagrass responses to herbivore pressure, several parameters were measured inside and outside the MPA: Sarpa salpa abundance (almost the only fish herbivore in the Western Mediterranean; Tomás et al. 2005, Prado et al. 2007), the percent of fish herbivory marks on Posidonia oceanica leaves (to corroborate the impact of herbivory on plants in the 2 areas), shoot surface area, rhizome carbohydrate storage, shoot density and flower production. 


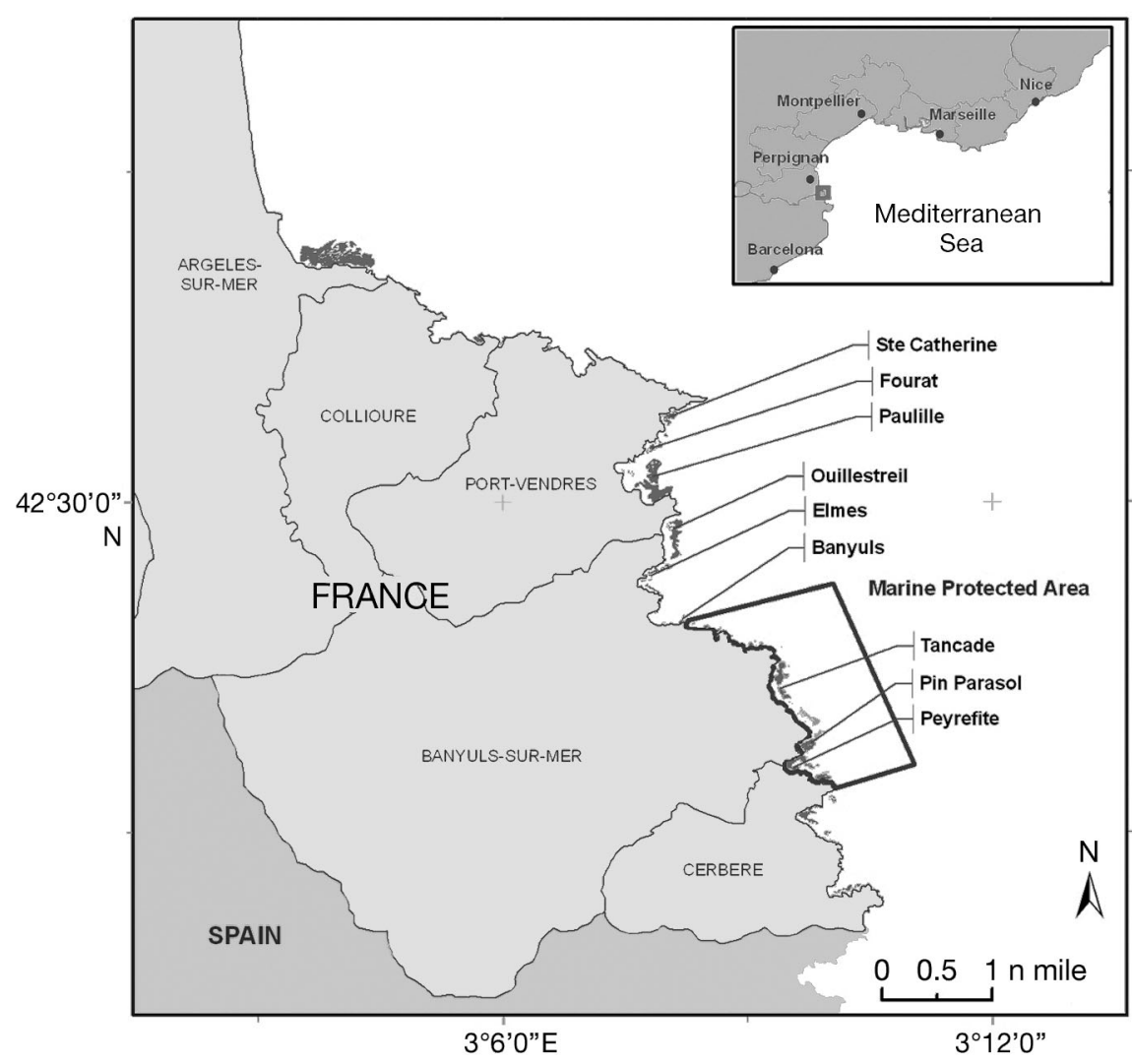

Fig. 1. Posidonia oceanica seagrass meadows on the Albères coast. The Marine Natural Reserve of Cerbère and Banyuls is located between L'Ile Grosse and Cap Peyrefite, and covers 650 ha with a total shore distance of $6.5 \mathrm{~km}$

(October 2004; Prado et al. 2007), 7 Posidonia oceanica shoots were randomly collected in 3 different zones per site $(n=21)$. For each shoot, the total number of leaves, the length and width of each leaf and the presence of fish herbivory marks were measured. Fish herbivores leave a distinctive bite mark of clearly identifiable shape (Boudouresque \& Meinesz 1982). Additionally, the rhizome was used to estimate total sugar (sucrose and starch) content. We pooled 7 shoots per zone for the sugar content analysis, since it required large amounts of tissue. Samples were dried $\left(70^{\circ} \mathrm{C}\right.$ for $24 \mathrm{~h}$ ), ground and then analysed following the colorimetric method described by Brink et al. (1960).

Shoot density and flower production: The number of shoots and flowers was measured at the end of October (the time of flower production) using 7 replicate random quadrats $(20 \times 20 \mathrm{~cm})$ in 3 zones in each meadow (21 replicates per site).

Caging experiment. The caging experiment was carried out at Posidonia oceanica meadow in Tancade Bay located at $7 \mathrm{~m}$ depth inside the MPA. Seagrass shoot density is on average

Fish abundance: At each of the 9 sampling sites (3 protected and 6 unprotected), abundance of Sarpa salpa was estimated using a timed underwater video count (Raventos et al. 2009). A total of 21 video samples per site were collected on different days throughout the summer period (from July to August 2004), the period of maximum fish abundance and activity (Tomás et al. 2005, Prado et al. 2007). The video clips (10 min each) give a relative measure of the number of fish observed per minute at each site. Fish size was also estimated directly to the nearest $\mathrm{cm}$ with the aid of a graded plate $(2 \times 2 \mathrm{~cm})$ and by visual estimation of distance using methodologies described by Mantyka \& Bellwood (2007). In order to minimize errors in fish size and number estimations, the graded plate and the fish were filmed at the same time to confirm the data estimated from direct surveys. Data on abundance and fish size from the 21 samples were averaged at each site. Finally, fish biomass at each meadow was derived from abundance and fish size data following a lengthweight relationship (Weight $=0.034 \times \mathrm{Size}^{2.73} ; \mathrm{R}^{2}=0.9$; Raventos et al. 2009).

Fish herbivory marks and shoot parameters: At the end of the period of maximum herbivore intensity
500 shoots $\mathrm{m}^{2}$ at this depth (Ferrari et al. 2008), and the meadow holds large schools of the herbivorous fish Sarpa salpa, with fish often being $>35 \mathrm{~cm}$ long (Raventos et al. 2009). Such a high density of fishes results in strong herbivore pressure (Prado et al. 2008, Raventos et al. 2009).

We set up a caging experiment with 3 replicate cages to prevent access of fish to plots of seagrass in the protected meadow. The cages measured $3 \times 3 \times 2 \mathrm{~m}\left(18 \mathrm{~m}^{3}\right)$, large enough to accommodate a diver for sampling inside. To avoid possible caging effects, we restricted all sampling to the central square meter of the exclosure. Fences were made of $5 \mathrm{~mm}$ mesh netting attached to the seafloor with $40 \mathrm{~cm}$ long iron pickets every $30 \mathrm{~cm}$ along the floor of the cage. The roof of the cages was made of a coarser mesh, and in order to avoid any potential cageinduced artefact of light reduction, we cleaned the roofs and walls of the cage weekly, comparable to the fortnightly cleaning of Tomás et al. (2005). We can therefore assume that any light reduction effect was negligible. Additionally, 3 control plots of equal size were marked with pickets and barrier nets in the vicinity of the cages, in the same Posidonia meadow, to control for artefacts due to location. 
Initial reference samples ( 7 shoots per plot) were taken both inside and outside the experimental plots ( 3 plots, 2 treatments, 7 samples, $\mathrm{n}=42$ ) immediately before the exclusion began in early June 2004. Sampling was then performed monthly from June to October, matching the more intense grazing period of Sarpa salpa. At each sampling time, 7 shoots were removed from the 6 plots (3 cages and 3 controls) and frozen for morphological and biochemical analysis. Care was always taken to sample from the centre of the exclosure (to minimize caging effects). For each collected shoot, total number of leaves, the percentage of fish herbivore marks, and the length and width of each leaf were measured. Total non-structural carbohydrates where measured in subsamples of dried rhizomes $\left(70^{\circ} \mathrm{C}\right.$ for $\left.24 \mathrm{~h}\right)$ by pooling all 7 shoots to increase biomass ( $n=3$ per treatment). Soluble carbohydrates were measured as above. In order to determine the flower density inside and outside the cages, flowers were counted in 7 quadrats of $20 \times 20 \mathrm{~cm}$ randomly placed in each of the 6 plots. This sampling was only carried out during the period of maximum inflorescence (October).

Statistical analysis. We used asymmetrical analyses of variance to test for differences between protected and unprotected meadows and 2-way ANOVAs for the caging experiments. Asymmetrical after control impact (ACI) designs, their mechanisms and potential for detecting spatio-temporal changes are discussed in Glasby (1997) and Underwood (1994). The dependent variables were the abundance of herbivore fish Sarpa salpa, the mean size of $S$. salpa, the total biomass of $S$. salpa, Posidonia oceanica shoot surface, fish herbivory marks, rhizome sugar content, shoot density and flower density. One site (Pin Parasol; Fig. 1) was excluded from the analysis of shoot density because it was at an average depth of $12 \mathrm{~m}$ as opposed to $7 \mathrm{~m}$ for all other sites, and shoot density is strongly influenced by depth (Bay 1984).

In the present study, the 'Protected versus Non-protected Location' factor was considered fixed, while the term 'Between Non-protected Locations' was random. Meadows (=sites) were randomly nested within Location, and Zones within Meadow. First, the data from both protected and non-protected locations were analysed using a fully orthogonal design in which meadows were nested in locations. A second analysis was then done on only those data associated to non-protected locations. The asymmetrical components were thus calculated by subtracting the sums of the squares of the second analysis from those of the first. The remainder represents the variance associated with the protected locations.

Prior to the statistical analyses, normality and homogeneity of variance were checked for all data (Kolmogorov-Smirnov test and Cochran's test, respectively). All differences were considered significant at $\mathrm{p}<0.05$. If transformations did not produce homogeneous variances, ANOVA was nevertheless used after setting alpha $=0.01$ in order to compensate for the increased likelihood of Type I error (Underwood 1997).

In the exclusion experiment, differences in all the measured parameters (shoot surface, fish herbivory marks) between control plots and cages were compared using a 2-way mixed ANOVA with treatment (cage vs. control) as a fixed factor and plot (3 plots per treatment) nested in treatment as a random factor $(\mathrm{n}=$ 7 ). Differences between inflorescence abundance and sugar content (1 replicate per plot) between control plots and cages were compared with a 1-way ANOVA with treatment (control plots vs. cages) as a fixed factor $(n=3)$. All the comparisons were made using data from the end of the experiment (October), but we present the data from previous months when available (for herbivore marks, shoot surface and sugar content) to show monthly trends. All statistical analyses were performed in the software package Statistica V.7.

\section{RESULTS}

\section{Abundance and biomass of the fish Sarpa salpa}

Sarpa salpa abundance and biomass differed significantly between MPA and unprotected meadows (Table 1). The number of $S$. salpa recorded inside MPA localities was higher than outside the protected area

Table 1. Summary of asymmetrical ANOVAs testing differences between protected and control locations. Only tests relevant to the hypotheses are reported. ${ }^{*} \mathrm{p}<0.05 ;{ }^{* *} \mathrm{p}<0.01 ; \mathrm{NS}=$ not significant

\begin{tabular}{|lrrc|}
\hline & df & $F$ & $\mathrm{p}$ \\
\hline Fish abundance (no. of fish per min of film) & 1 & 7125.51 & ${ }^{* *}$ \\
Mean length of fishes (cm) & 1 & 166.64 & ${ }^{*}$ \\
Mean biomass of fishes (g) & 1 & 513.36 & ${ }^{*}$ \\
Fish herbivory marks on leaves (\%) & 1 & 223.88 & ${ }^{*}$ \\
Meadow density (shoots $\mathrm{m}^{-2}$ ) & 1 & 2.88 & ${ }^{*}$ \\
Posidonia shoot surface $\left(\mathrm{cm}^{2}\right.$ per shoot) & 1 & 1367.57 & ${ }^{* *}$ \\
Posidonia sugar concentration ${ }^{\text {a }}\left(\mathrm{mg} \mathrm{g}^{-1}\right.$ ) & 1 & 27.34 & ${ }^{*}$ \\
Number of inflorescences in Posidonia ${ }^{\text {b }}$ (no. $\mathrm{m}^{-2}$ ) & 1 & 800.33 & $\mathrm{NS}^{\mathrm{c}}$ \\
${ }^{\mathrm{a}}$ Tested against the pooled term (the overall residual) & & \\
${ }^{\text {b} V a r i a n c e s ~ w e r e ~ h e t e r o g e n e o u s ~(a s ~ i n d i c a t e d ~ b y ~ C o c h r a n ' s ~ C ~ t e s t) ~ a n d ~ c o u l d ~}$ \\
not be stabilized by transformation \\
${ }^{\mathrm{c}}$ Term is not significant according to the more conservative $\alpha$ (alpha) level \\
adopted in analyses where variances were not stabilized by transformations \\
\hline
\end{tabular}



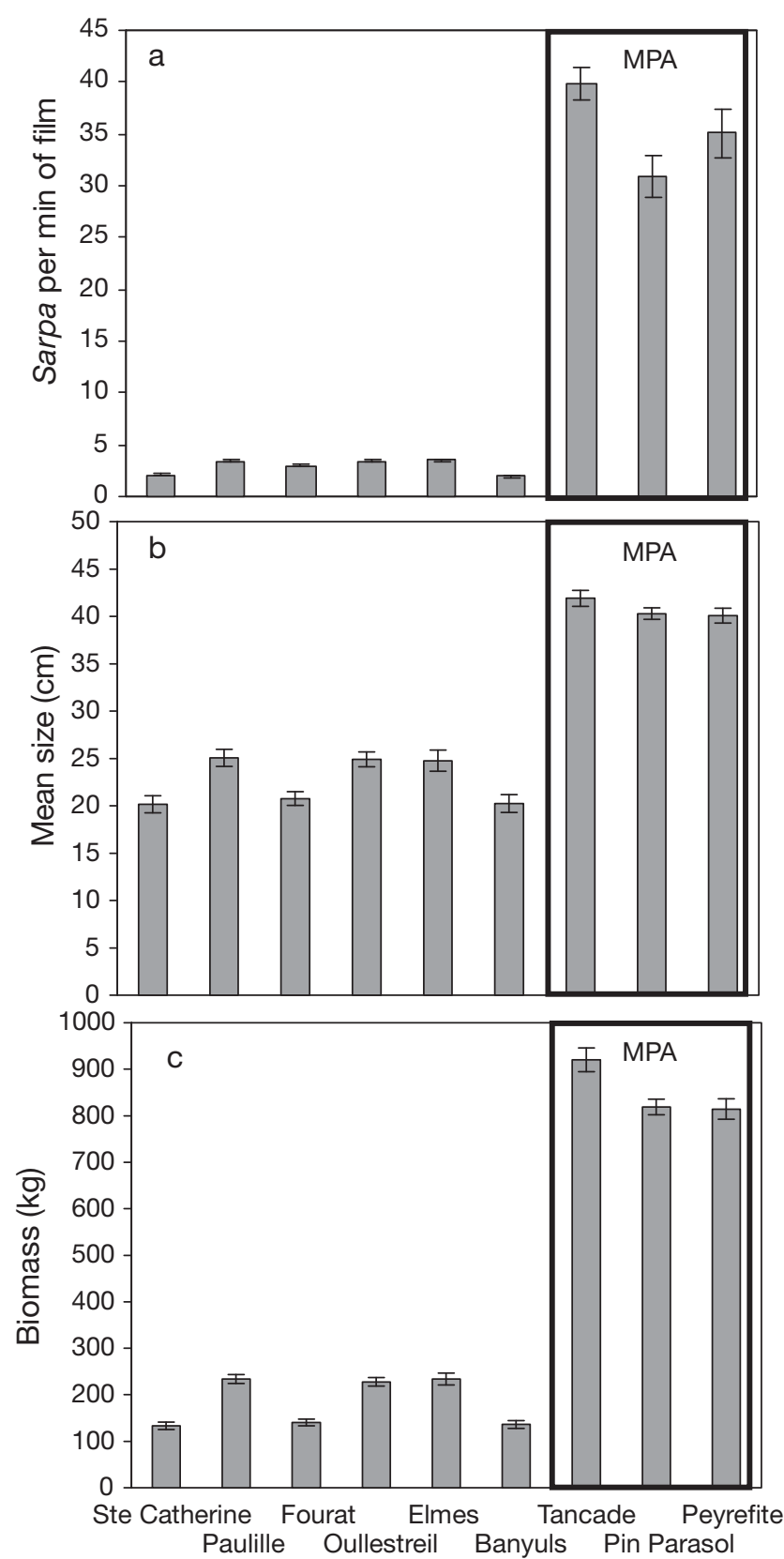

Fig. 2. Sarpa salpa. (a) Mean number of individuals observed per minute of film, (b) mean length and (c) mean biomass. Error bars represent standard errors. Box represents meadows in the Marine Protected Area (MPA)

(Fig. 2a). S. salpa size was also consistently higher inside the MPA sites than outside, leading to a herbivore biomass 10 times higher inside the MPA (Table 1, Fig. 2b,c).

\section{Fish herbivory marks on seagrass}

The percent of adult leaves showing fish herbivory marks was higher in the MPA meadows compared to un-

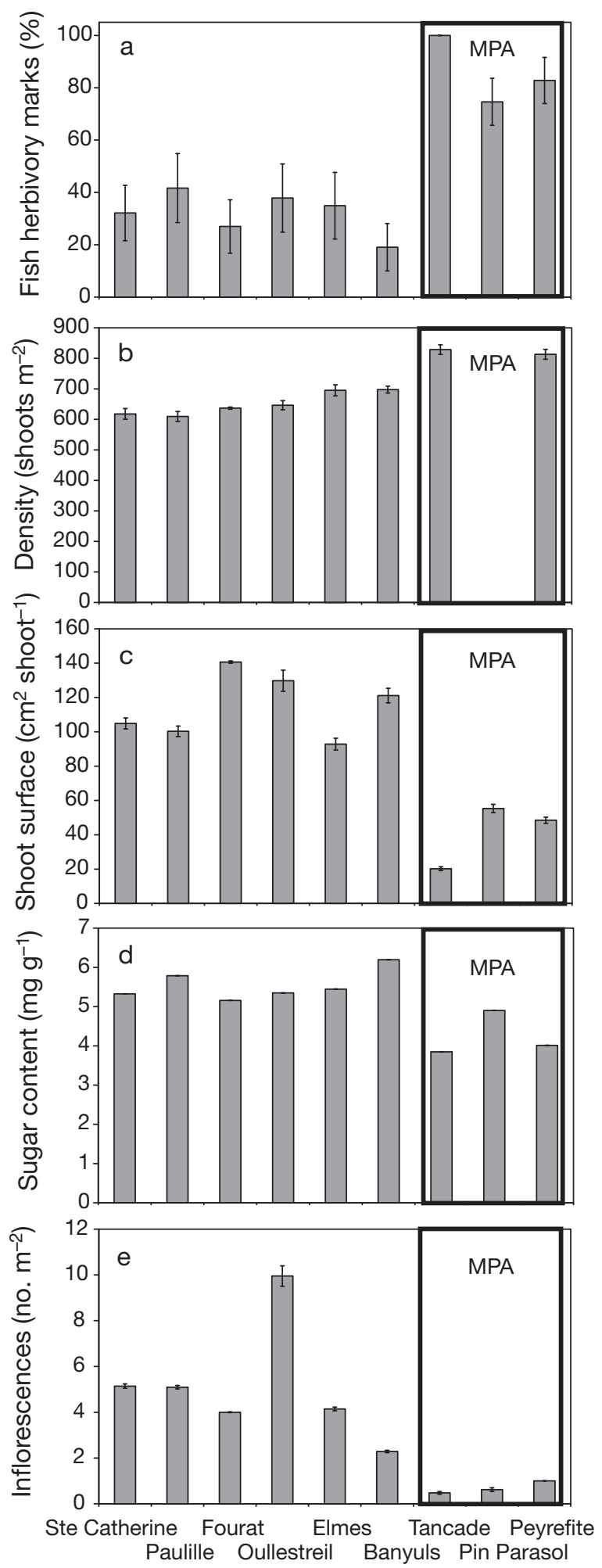

Fig. 3. Posidonia oceanica. (a) Fish herbivory marks on seagrass, (b) shoot density, (c) shoot surface, (d) sugar content and (e) number of inflorescences at each of the studied locations. Pin Parasol is not included in the density graph due to its deeper location. Error bars represent standard errors. Box represents meadows in the Marine Protected Area (MPA) 
protected ones (Table 1, Fig. 3a). Within the control experiments, the percent of adult leaves showing fish herbivory marks by Sarpa salpa inside the cages was much lower than outside the cages at the end of the experiment after 4 mo (Fig. 4a). Leaves outside the cages
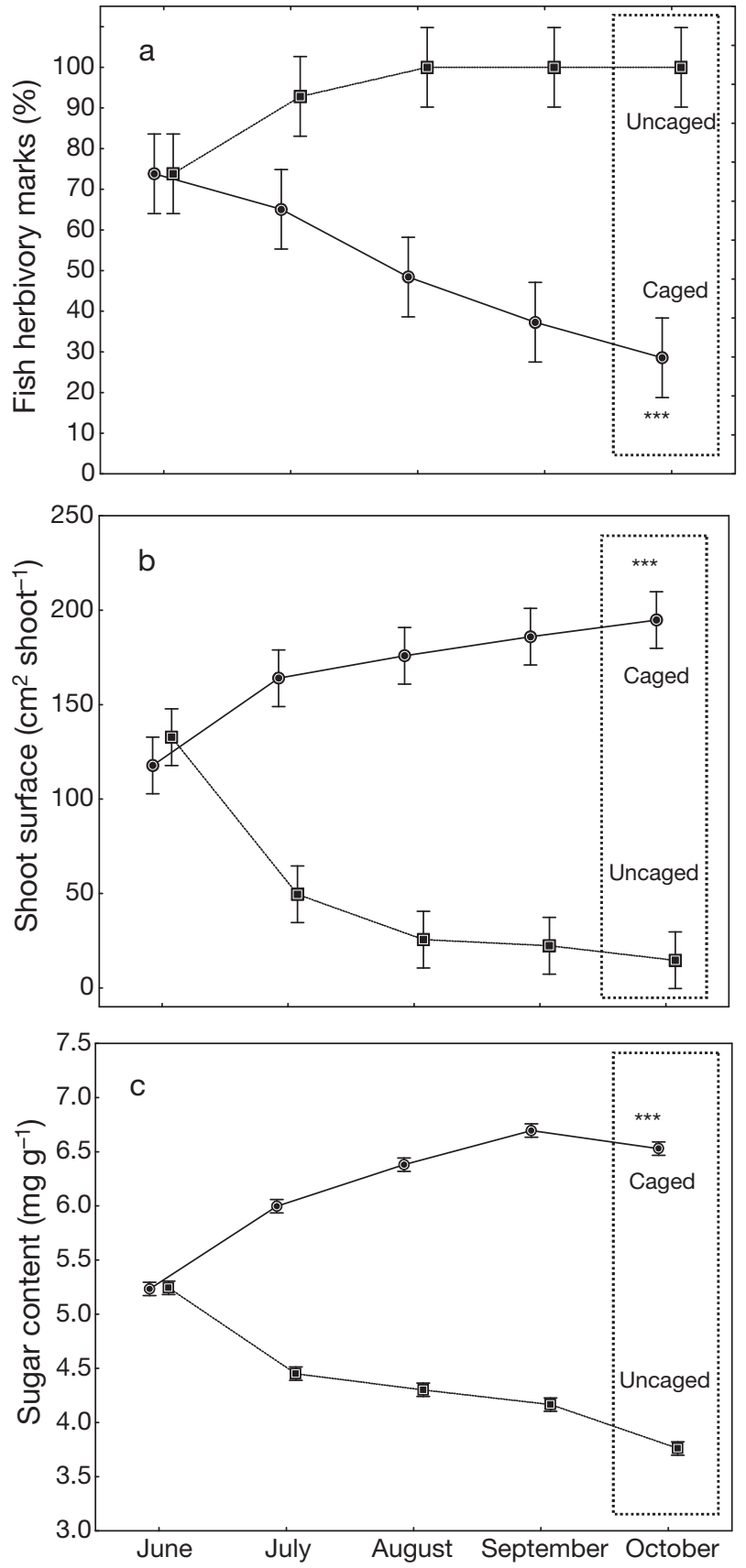

Fig. 4. Posidonia oceanica. (a) Temporal changes in fish herbivory marks, (b) shoot surface and (c) sugar content in shoots after adding cages (O) and in uncaged (ㅁ) plots. Significant differences between treatments at the end of the experiment were detected using $(a, b) 2$-way mixed ANOVA with Treatment as fixed factor and Plot as random factor nested in Treatment or (c) 1-way ANOVA with Treatment as fixed factor. Differences are indicated by ${ }^{* * *}(\mathrm{p}<0.0001)$ showed an increased percentage of herbivory marks linked to the arrival of S. salpa. Three months after the arrival of $S$. salpa, all leaves showed fish herbivory marks. Inside the cages, the trend was reversed, decreasing from $70 \%$ herbivory at the beginning of the experiment to values of $30 \%$ at the end of the experimental period (Fig. 4a).

\section{Seagrass dynamics}

Shoot density was $30 \%$ higher inside the MPA than in unprotected meadows (Table 1, Fig. 3b). No significant difference was detected in shoot density inside versus outside exclusion cages at the end of the experimental period $(F=0.105, \mathrm{p}>0.5)$.

Fish herbivory modified the morphometrics of Posidonia oceanica shoots in both natural and experimental conditions. This trend was reflected in our observational studies between protected and unprotected meadows, with shoot surface measurements 3 times lower in meadows inside the MPA (Table 1, Fig. 3c). Shoot surface area also responded to the herbivore exclusion. Inside the cages, shoot surface area was 10 times higher than in the surrounding meadow at the end of the experimental period (Fig. 4b). At the beginning of the experiment, both treatments had the same shoot surface area (around $120 \mathrm{~cm}^{2}$ shoot ${ }^{-1}$ ). With the arrival of Sarpa salpa schools, shoot surface area decreased progressively outside the cages with values near zero at the end of the experiment (Fig. 4b). Inside the cages, where fish herbivory was excluded, shoot surface area nearly doubled during the same period (Fig. 4b). However, total shoot surface area inside the cages was still larger than in unprotected meadows, indicating that low-level herbivory by fish does occur in the meadows located outside the MPAs.

\section{Seagrass physiology (sugar content)}

Throughout the experiment, the sugar content of Posidonia oceanica was higher than $5 \mathrm{mg} \mathrm{g}^{-1}$ outside the MPA as opposed to values close to $4 \mathrm{mg} \mathrm{g}^{-1}$ inside the MPA (Table 1, Fig. 3c). Similar significant differences appeared when comparing sugar content in the control experiments, with values of around $6.5 \mathrm{mg} \mathrm{g}^{-1}$ inside the exclosures compared to approximately 3.5 $\mathrm{mg} \mathrm{g}^{-1}$ in the control plots at the end of the experiment (Fig. 4c). Both treatments (inside and outside the cage) showed similar values at the beginning of the experiment (Fig. 4c) and then developed differently: sugar content progressively increased within the fish exclusion cages, while it decreased continuously outside the cages over time (Fig. 4c). 


\section{Incidence of sexual reproduction (flowering)}

The number of flowers in meadows outside the MPA, with low level of herbivory, reached on average 6 inflorescences $\mathrm{m}^{-2}$ compared to 0.4 inflorescences $\mathrm{m}^{-2}$ observed in protected meadows (Table 1). Herbivore exclusion also resulted in higher values of flowering, with 1.7 inflorescences $\mathrm{m}^{-2}$ inside cages, compared to 0.4 inflorescences $\mathrm{m}^{-2}$ observed outside (Fig. 5).

\section{DISCUSSION}

Posidonia oceanica is able to cope with sustained high herbivory (more than $20 \mathrm{yr}$ of intense grazing) with a remarkable ability to reallocate its resources between sexual reproduction and population growth. Our results indicate that under high herbivore pressure, carbon storage in the rhizome decreases substantially, flower production is depressed, and shoot density increases significantly compared with areas of low herbivory. Our short-term exclusion experiments directly linked these trends to a high herbivory pressure (80\% of photosynthetic tissue subtraction), confirming both the increase in carbon storage and flowering when herbivores were excluded. As expected, shoot density showed no change inside the cages. $P$. oceanica, being long-lived, would probably require an unfeasibly long experimental exclusion to respond at the population level. Our comparative design served as the best proxy for these long-term conditions, as the dominant herbivore Sarpa salpa has very low densities outside the MPA.

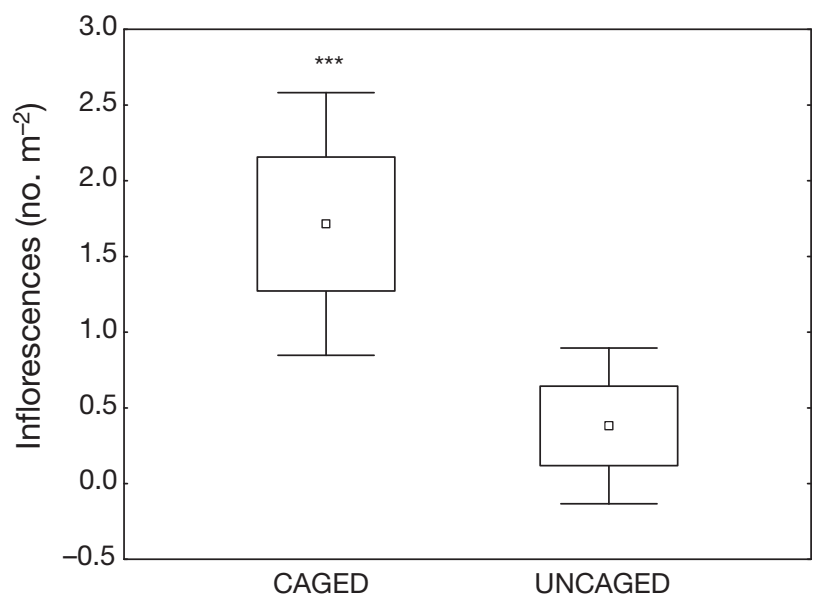

Fig. 5. Posidonia oceanica. Density of inflorescences (mean \pm $\mathrm{SE})$ between caged and uncaged plots during the inflorescence period (October). Small square: mean; box: variance; whiskers: SE. Significant differences between treatments (1-way ANOVA with Treatment as fixed factor) are shown $\left({ }^{* * *} \mathrm{p}<0.0001\right)$
The putative adaptive response of Posidonia oceanica is particularly remarkable given the timing of herbivory. Fish herbivory peaks during the summer months (Tomás et al. 2005), which is also a crucial time for carbon accumulation, when the plant invests heavily in building up its overwintering storage reserves (Alcoverro et al. 2001). Under intense grazing, seagrasses will end up drawing substantially on these reserves to compensate for severely reduced rhizome carbon acquisition. This could dramatically compromise the plant's ability to overwinter effectively. Surprisingly, our study indicates that in the face of this dual reduction (loss of leaf biomass to herbivory and loss of rhizome storage), plants respond by allocating their resources towards increased clonal growth. The first priority for the plant is to grow new material and hence restore photosynthetic capacity as observed in the cage experiment during the period of maximum growth. This prioritisation has also been observed in terrestrial grasses where the sequence of allocation of soluble carbon and nitrogen reserves always starts with the increase of photosynthetic tissue through plant re-growth before investing in inflorescences (Turner et al. 2007). At low to moderate herbivory, clipping experiments have shown that $P$. oceanica is perfectly capable of compensating shoot reduction with growth (Vergés et al. 2007). However, at high to very high levels of grazing, such as experienced in the MPA, other mechanisms may be necessary to increase photosynthetic tissue. As the top canopy is grazed down by Sarpa salpa, more light reaches the otherwise shaded understorey of the meadow: the increased shoot production recorded in our study could help maximize light acquisition and carbon production (Valentine et al. 1997). This increased shoot density may be necessary to maintain overall plant production levels under intense grazing pressure. In addition, clonal propagation is also a potential mechanism to minimize the negative effects of herbivory by spreading the risk of attack (Piqueras 1999).

Our observations clearly demonstrate a lower flower production in highly grazed systems, with lower carbon reserves concomitant with an increase in shoot density, that together suggest a reallocation of carbon reserves away from sexual reproduction and towards vegetative growth. This decrease in flower production occurs in addition to the loss of flowers and fruits by direct herbivore consumption (Piazzi et al. 2000, Balestri \& Cinelli 2003, Vergés et al. 2007). It may be argued that over long time scales, this decreased sexual reproductive effort could result in lower genetic viability of the meadow and therefore lead to a lack of plasticity at evolutionary time scales. In fact, studies of the genetic structure of Posidonia oceanica point to a very low genetic variability, often attributed to their low and pulsed flower production (plants only flower 
every $7 \mathrm{yr}$ ) and low within-meadow recruitment (Migliaccio et al. 2005). However, the relationship between population-level flower production and meadow genetic structure is complex, and herbivory may actually facilitate an increase in external recruitment and genetic flow as has been observed in some terrestrial meadows (Reisch \& Scheitler 2009). This requires herbivore-free refuges to serve as source areas within the metapopulation (Arnaud-Haond et al. 2007, Rozenfeld et al. 2008). Deeper P. oceanica meadows, where herbivores do not forage (Tomás et al. 2005) could serve as refuges from herbivory, and thus facilitate genetic flow, although low genetic flow seems to occur between shallow and deep meadows (Procaccini \& Mazzella 1998, Migliaccio et al. 2005). In addition, most unprotected, shallow meadows today have very low densities of Sarpa salpa and may also supply recruits to highly grazed meadows.

In general, our results appear to indicate that Posidonia oceanica demonstrates a remarkably plastic population-level response to sustained high grazing. At first this plasticity is surprising, since few locations in the Mediterranean currently have herbivory pressures as high as encountered in the Banyuls MPA. These unusual abundances are a direct result of longterm protection from fishing, and herbivores concentrate their grazing on the meadows inside the reserve (Prado et al. 2008). It is possible that these intense levels of herbivory, while more the exception than the rule in the present, were potentially much more common in the historical and evolutionary past. Historical populations of herbivorous green turtles and fish could have been several orders of magnitude higher in the Mediterranean. Today, green turtle populations are restricted to the Eastern Mediterranean, while fish populations are reduced throughout their ranges, apart from in MPAs (Prado et al. 2008). At evolutionary time scales, $P$. oceanica meadows potentially coexisted with mega-herbivores including seagrass specialist sirenians (Pérès 1985, Domning \& Thomas 1987). Given this long shared history of coexistence with high densities of herbivores, it may have been necessary for $P$. oceanica to develop morphological, population and genetic-level strategies to deal with regular and sustained grazing. This study suggests that under these conditions of intense herbivory, seagrass systems of the past would have been considerably different in their population structure than the meadows we see today. Protected areas may have transformed seagrass systems back to these historical conditions, but it remains to be established what the longer-term consequences of these management actions are on seagrass functional values, and whether seagrass deals with intense grazing over long time scales.
Acknowledgements. We thank M. Licari, J. Laffon and J. Binche for assistance in the field. The Réserve Naturelle Marine de Cerbère-Banyuls and the Conseil general des Pyrénées Orientales provided essential logistic support. Research was supported by the Conseil general des Pyrénées Orientales, the Région Languedoc-Roussillon and CNRS and EPHE internal grants. T.A. was supported by a grant from Plan Nacional (CTM2010-22273-C02-02, subprogramme MAR).

\section{LITERATURE CITED}

Alcoverro T, Mariani S (2002) Effects of sea urchin grazing on Thalassodendron ciliatum seagrass beds of a Kenyan lagoon. Mar Ecol Prog Ser 226:255-263

Alcoverro T, Mariani S (2004) Patterns of fish and sea urchin grazing on tropical Indo-Pacific seagrass beds. Ecography 27:361-365

Alcoverro T, Mariani S (2005) Shoot growth and nitrogen responses to simulated herbivory in Kenyan seagrasses. Bot Mar 48:1-7

> Alcoverro T, Manzanera M, Romero J (2001) Annual metabolic carbon balance of the seagrass Posidonia oceanica: the importance of carbohydrate reserves. Mar Ecol Prog Ser 211:105-116

Arnaud-Haond S, Migliaccio M, Diaz-Almela E, Teixeira S and others (2007) Vicariance patterns in the Mediterranean Sea: east-west cleavage and low dispersal in the endemic seagrass Posidonia oceanica. J Biogeogr 34: 963-976

Balestri E, Cinelli F (2003) Sexual reproductive success in Posidonia oceanica. Aquat Bot 75:21-32

Bay D (1984) A field-study of the growth dynamics and productivity of Posidonia oceanica (L.) Delile in Calvi Bay, Corsica. Aquat Bot 20:43-64

Boudouresque CF, Meinesz A (1982) Découverte de l'herbier de Posidonies. Cah Parc Natl Port-Cros 4:1-79

Boudouresque CF, Verlaque M (2001) Ecology of Paracentrotus lividus. In: Lawrence JM (ed) Edible sea urchins: biology and ecology. Elsevier, Amsterdam, p 177-216

> Brink RH Jr, Dubach P, Lynch DL (1960) Measurement of carbohydrates in soil hydrolyzates with anthrone. Soil Sci 89:157-166

Cumming DHM (1982) The influence of large herbivores on savanna structure in Africa. Ecol Stud 42:217-245

Domning D, Thomas H (1987) Metaxytherium serresii (Mammalia: Sirenia) from the Early Pliocene of Libya and France: a reevaluation of its morphology, phyletic position, and biostratigraphic and paleoecological significance. In: Boaz NT, El-Arnauti A, Gaziry AW, de Heinzelin J, Boaz D (eds) Neogene paleontology and geology of Sahabi. Alan R. Liss, New York, NY, p 205-232

Dublin HT (1995) Vegetation dynamics in the Serengeti-Mara ecosystem: the role of elephants, fire, and other factors. In: Sinclair ARE, Arcese P (eds) Serengeti II: dynamics, management, and conservation of an ecosystem. University of Chicago Press, Chicago, IL, p 71-90

Ferrari B, Raventos N, Planes S (2008) Assessing effects of fishing prohibition on Posidonia oceanica seagrass meadows in the Marine Natural Reserve of Cerbère-Banyuls. Aquat Bot 88:295-302

Ferraro DO, Oesterheld M (2002) Effect of defoliation on grass growth. A quantitative review. Oikos 98:125-133

> Francour P (1997) Fish assemblages of beds at Port-Cros (France, NW Mediterranean): assessment of composition and long-term fluctuation by visual census. PSZN I: Mar Ecol 18:157-173 
Glasby TM (1997) Analyzing data from post-impact studies using asymmetrical analyses of variance: a case study of epibiota on marinas. Aust J Ecol 22:448-459

Harmelin-Vivien ML (1983) Étude comparative de l'ichtyofaune des herbiers de phanérogames marines en milieux tropical et tempéré. Rev Ecol Terre Vie 38:179-210

Harper JL (1977) Population biology of plants. Academic Press, New York, NY

Heck KL Jr, Valentine JF (2006) Plant-herbivore interactions in seagrass meadows. J Exp Mar Biol Ecol 330:420-436

Jackson JBC, Kirby MX, Berger WH, Bjorndal KA and others (2001) Historical overfishing and the recent collapse of coastal ecosystems. Science 293:629-638

Kleijn D, Steinger T (2002) Contrasting effects of grazing and hay cutting on the spatial and genetic population structure of Veratrum album, an unpalatable, long-lived, clonal plant species. J Ecol 90:360-370

Mantyka CS, Bellwood DR (2007) Direct evaluation of macroalgal removal by herbivorous coral reef fishes. Coral Reefs 26:435-442

Marbà N, Duarte CM, Cebriàn J, Gallegos ME, Olesen B, SandJansen K (1996) Growth and population dynamics of Posidonia oceanica on the Spanish Mediterranean coast: elucidating seagrass decline. Mar Ecol Prog Ser 137:203-213

Mateo MA, Romero J, Perez M, Littler MM, Littler DS (1997) Dynamics of millenary organic deposits resulting from the growth of the Mediterranean seagrass Posidonia oceanica. Estuar Coast Shelf Sci 44:103-110

McClanahan TR, Arthur R (2001) The effect of marine reserves and habitat on populations of East African coral reef fishes. Ecol Appl 11:559-569

McClanahan TR, Graham NAJ (2005) Recovery trajectories of coral reef fish assemblages within Kenyan marine protected areas. Mar Ecol Prog Ser 294:241-248

McNaughton SJ (1979) Grazing as an optimization process: grass ungulate relationships in the Serengeti. Am Nat 113: 691-702

McNaughton SJ, Banyikwa FF (1995) Plant communities and herbivory. In: Sinclair ARE, Arcese P (eds) Serengeti II: dynamics, management, and conservation of an ecosystem. University of Chicago Press, Chicago, IL, p 49-70

Migliaccio M, De Martino F, Silvestre F, Procaccini G (2005) Meadow-scale genetic structure in Posidonia oceanica. Mar Ecol Prog Ser 304:55-65

Mulder CPH (1999) Vertebrate herbivores and plants in the Arctic and subarctic: effects on individuals, populations, communities and ecosystems. Perspect Plant Ecol Evol Syst 2:29-55

Owen DF, Wiegert RG (1976) Do consumers maximize plant fitness? Oikos 27:488-492

Paige KN, Whitham TG (1987) Overcompensation in response to mammalian herbivory: the advantage of being eaten. Am Nat 129:407-416

Pérès JM (1985) History of the Mediterranean biota and the colonization of the depths. In: Margalef R (ed) Western Mediterranean. Pergamon Press, Oxford, p 198-232

> Peterken CJ, Conacher CA (1997) Seed germination and recolonisation of Zostera capricorni after grazing by dugongs. Aquat Bot 59:333-340

Piazzi L, Balestri E, Cinelli F (2000) Grazing of inflorescences of the seagrass Posidonia oceanica (L.) Delile. Bot Mar 43:581-584

Piqueras J (1999) Herbivory and ramet perfomance in the clonal herb Trientales europaea L. J Ecol 87:450-460

Prado P, Tomas F, Alcoverro T, Romero J (2007) Extensive

Editorial responsibility: Konstantinos Stergiou,

Thessaloniki, Greece direct measurements of Posidonia oceanica defoliation confirm the importance of herbivory in temperate seagrass meadows. Mar Ecol Prog Ser 340:63-71

- Prado P, Farina S, Tomas F, Romero J, Alcoverro T (2008) Marine protection and meadow size alter fish herbivory in seagrass ecosystems. Mar Ecol Prog Ser 371:11-21

> Preen AR (1995) Impacts of dugong foraging on seagrass habitats: observational and experimental evidence for cultivation grazing. Mar Ecol Prog Ser 124:201-213

Procaccini G, Mazzella L (1998) Population genetic structure and gene flow in the seagrass Posidonia oceanica assessed using microsatellite analysis. Mar Ecol Prog Ser 169:133-141

> Raventos N, Planes S, Ferrari B (2009) Changes in population parameters and behaviour of the herbivorous fish Sarpa salpa in protected and unprotected seagrass meadows in the north-western Mediterranean. J Mar Biol Assoc UK 89:1153-1159

Reisch C, Scheitler S (2009) Disturbance by mowing affects clonal diversity: the genetic structure of Ranunculus ficaria (Ranunculuaceae) in meadows and forests. Plant Ecol 201:699-707

Rose CD, Sharp WC, Kenworthy WJ, Hunt JH and others (1999) Overgrazing of a large seagrass bed by the sea urchin Lytechinus variegatus in Outer Florida Bay. Mar Ecol Prog Ser 190:211-222

Rozenfeld AF, Arnaud-Haond S, Hernandez-Garcia E, Eguíluz VM, Serrão EA, Duarte CM (2008) Network analysis identifies weak and strong links in a metapopulation system. Proc Natl Acad Sci USA 105:18824-18829

Russ GR, Alcala AC (2004) Marine reserves: long-term protection is required for full recovery of predatory fish populations. Oecologia 138:622-627

Sinclair ARE (1995) Equilibria in plant-herbivore interactions. In: Sinclair ARE, Arcese P (eds) Serengeti II: dynamics, management, and conservation of an ecosystem. University of Chicago Press, Chicago, IL, p 91-113

Tomás F, Turón X, Romero J (2005) Seasonal and small-scale spatial variability of herbivore pressure on the temperate seagrass Posidonia oceanica. Mar Ecol Prog Ser 301:95-107

Turner LR, Donaghy DJ, Lane PA, Rawnsley RP (2007) Patterns of leaf and root regrowth, and allocation of watersoluble carbohydrate reserves following defoliation of plants of prairie grass (Bromus willdenowii Kunth.). Grass Forage Sci 62:497-506

Underwood AJ (1994) On beyond BACI: sampling designs that might reliably detect environmental disturbances. Ecol Appl 4:3-15

Underwood AJ (1997) Experiments in ecology: their logical design and interpretation using analysis of variance. Cambridge University Press, Cambridge

Valentine JF, Heck KL Jr (1999) Seagrass herbivory: evidence for the continued grazing of marine grasses. Mar Ecol Prog Ser 176:291-302

Valentine JF, Heck KL, Busby J Jr, Webb D (1997) Experimental evidence that herbivory increases shoot density and productivity in a subtropical turtlegrass (Thalassia testudinum) meadow. Oecologia 112:193-200

Vergés A, Becerro MA, Alcoverro T, Romero J (2007) Variation in multiple traits of vegetative and reproductive seagrass tissues influences plant-herbivore interactions. Oecologia 151:675-686

Vergés A, Pérez M, Alcoverro T, Romero J (2008) Compensation and resistance to herbivory in seagrasses: induced responses to simulated consumption by fish. Oecologia 155:751-760

Submitted: March 9, 2010; Accepted: February 11, 2011

Proofs received from author(s): May 11, 2011 